\title{
Estimation of Phytochemical, Vitamins Composition and Antioxidant Activity of Pelargonium inquinans Leaves
}

\author{
Ogochukwu Izuegbuna' ${ }^{1}$, Gloria Otunola², Graeme Bradley ${ }^{1, *}$
}

\section{Ogochukwu Izuegbuna', Gloria Otunola², Graeme Bradley ${ }^{1, *}$}

'Department of Biochemistry, Faculty of Science and Agric. University of Fort Hare, Alice, 5700, SOUTH AFRICA. ${ }^{2}$ Department of Botany, Medicinal Plants and Economic Development (MPED) Research Institute, University of Fort Hare, 5700, SOUTH AFRICA.

\section{Correspondence}

\section{Prof. Graeme Bradley}

Department of Biochemistry and Microbiology, Faculty of Science and Agric, University of Fort Hare, Alice 5700, SOUTH AFRICA.

Phone no : +27 768343754

E-mail: GBradley@ufh.ac.za

\section{History}

- Submission Date: 16-08-2018:

- Review completed: 06-11-2018;

- Accepted Date: 26-11-2018.

DOI : 10.5530/pj.2019.11.37

\section{Article Available online}

http://www.phcogj.com/v11/i2

\section{Copyright}

(C) 2019 Phcog.Net. This is an openaccess article distributed under the terms of the Creative Commons Attribution 4.0 International license.

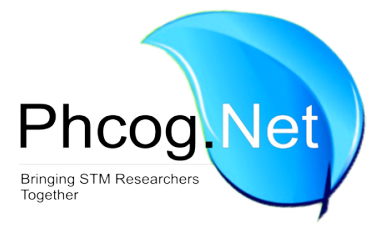

\begin{abstract}
Aims: To estimate the phytochemical and vitamins composition and the antioxidant activity of Pelargonium inquinans leaves. Background: Some plants that are used in the traditional setting for the management of different ailments have documented observations and scientific studies. However many other plants lack scientific reports to support their medicinal use. One of such plant is Pelargonium inquinans Ait that is traditionally used to treat headaches and flu by tribes in South Africa. Not much is known about its chemical composition. Methods: The phytochemical composition of acetone, aqueous and ethanol extract of leaves of Pelargonium inquinans as well as the vitamins A, C and E of its dried weight leaves and the antioxidant activities were evaluated using standard in vitro methods. The phytochemical composition and vitamins were determined spectrophotometrically, while the antioxidant activities were determined by DPPH, nitric oxide and hydrogen peroxide scavenging activity and phosphomolybdenum (total) antioxidant activity. Statistical analysis: The One-way analysis of variance (ANOVA) and the Tukey test were used to determine the differences among the means of the various samples. Results: The phytochemical composition differ significantly in the various extracts. The total phenolics were higher than other phytochemicals in all the extracts used. The hydrogen peroxide and DPPH scavenging activity were very high and dose-dependent. The aqueous extract had the highest antioxidant activity at $98.4 \%$ of control (Hydrogen peroxide), while the ethanol extract had the lowest at 37.5\% control (Nitric oxide). Conclusion:The results supports the notion that the Geraniaceae family and Pelargonium inquinans in particular is rich in polyphenolic compounds and has good antioxidant activity. Key words: Pelargonium inquinans, Phytochemical, Antioxidant, Vitamins, Phenols, Cancers. Key message: Pelargonium inquinans leaves are particularly rich in polyphenolic compounds and thus have good antioxidant activity.
\end{abstract}

\section{INTRODUCTION}

Over many centuries, plants have devised many mechanisms to repel attack by predators like insects and fungi by synthesizing different biochemical compounds. Many of these compounds have proved useful in the management of different human diseases. Phytochemicals are secondary metabolites found in plants with no nutritive value. They are known to biological activities such as antioxidation. ${ }^{1}$

Oxidative stress (OS) can be defined as a yin-yang relationship between free radicals/reactive oxygen species (ROS) generated as a result of some cellular (re)actions and antioxidants (Constitutive or endogenously) produced to either mollify or abrogate their effects. OS is important in health and disease, especially chronic diseases. It has both beneficial and deleterious effects. For example, OS has been shown to induce cell death and also enhance antimicrobial phagocytosis by the release of reactive oxygen species through the immune cells. ${ }^{2}$ They do this by acting as stress signals for certain signaling pathways and intermediates that modulate physiological processes. ${ }^{3}$ However, excessive production of ROS without a counterbalance by the innate antioxidant system will cause the cell to be stressed. OS is involved in many degenerative diseases and inflammatory conditions like atherosclerosis and cancer. ${ }^{4}$ ROS are produced as a result of endogenous and exogenous factors. The endogenous factors include cellular metabolites from mitochondria- catalyzed electron transport reactions and activities of leukocytes such neutrophils, eosinophil, monocytes and cellular organelle peroxisomes during inflammation (the enzymes involved in generating ROS are found in these cells and organelles, e.g., macrophages can trigger an increase in ROS during an inflammatory response). Exogenous factors include irradiation, various drugs and xenobiotic agents. ROS include superoxide anion $\left(\mathrm{O}_{2}{ }^{-}\right)$, hydrogen peroxide $\left(\mathrm{H}_{2} \mathrm{O}_{2}\right)$, hydroxyl radical $(\mathrm{HO} \bullet)$ and singlet oxygen $\left({ }^{1} \mathrm{O}_{2}\right)$. Superoxide anion can also combine with nitrous oxide (NO) to form Reactive nitrogen species (RNS). They can cause nitrosative stress from its various species which include 
peroxynitrite $\left(\mathrm{ONOO}^{-}\right)$, nitrosoperoxycarbonate $\left(\mathrm{ONOOCO}_{2}^{-}\right)$, nitrogen dioxide $\left(\bullet \mathrm{NO}_{2}\right)$ and dinitrogen trioxide $\left(\mathrm{N}_{2} \mathrm{O}_{3}\right)$.

The body has a defense network of antioxidants, which include the tripeptide glutathione and enzymes like superoxide dismutase and catalase, to nullify the harmful effects of free radicals on cells. These antioxidants are endogenous and are produced mainly in the mitochondria. Others include alpha lipoic acid (ALA), Coenzyme Q10 (CoQ10), glutathione peroxidase (Gpx), ferritin, uric acid, bilirubin, metallothionein, L-carnitine and melatonin. ${ }^{5}$ Where the endogenous antioxidants do not suffice, the exogenous ones which are acquired from foods can help out. These include vitamins such as $\mathrm{E}$ and $\mathrm{C}$ which are involved in the prevention of lipid peroxidation and enhancement of OS cells respectively. ${ }^{6,7}$ Other important exogenous antioxidants found in plants include phenolic compounds (phenolic acids, flavonoids, quinones, coumarins, lignans, stilbenes, tannins, etc.), nitrogen compounds (alkaloids, amines, betalains).

The effect of OS can be either acute or chronic. For chronic OS, a small amount of oxidative damage can persist during physiological functioning of the cell and lead to disruption of essential cellular functions and a premorbid state of carcinogenesis through the promotion of cell survival, ${ }^{8}$ cellular proliferation, ${ }^{9}$ metastasis, ${ }^{10}$ and even drug resistance. ${ }^{11}$ ROS plays a role in many cancers including haematological cancers. ${ }^{12,13}$ Acute myeloid leukaemia relapse has also been strongly associated with increased markers of oxidative stress, implying that ROS can be a pivotal factor in AML progression. ${ }^{1}$ Thus the regulation of OS is important in cancer growth and management and so a better understanding of it will aid in both the definitive and supportive care of various types of leukaemia. Pelargonium inquinans is a small to medium-sized woody shrub with velvety and glandular branches. Like most other Pelargonium species. It is indigenous to South Africa and found especially in the Eastern Cape up to southern Kwazulu- Natal. The plant's stems and leaves are crushed and used to treat headaches and flu by the local people, who also use it as a deodorant. ${ }^{14}$ The crude extracts have been reported to have strong antioxidant activity. ${ }^{15}$ While several species of the family Geraniaceae have been investigated, there is a paucity of information on the phytochemical composition and antioxidant activities of this species. Not much has been reported about Pelargonium inquinans in the literature and neither has the chemical composition of any of the parts of the plant been determined.

This present work was undertaken to estimate the total phenol, flavonoid, flavonol, proanthocyanidin, tannins, alkaloids, saponins and phytate contents in the water, acetone and ethanol extracts of Pelargonium inquinans leaves as well as the vitamins $\mathrm{A}, \mathrm{E}$ and $\mathrm{C}$ content and antioxidant activity.

\section{MATERIALS AND METHODS}

\section{Plant material}

The leaves of Pelargonium inquinans were collected from the plant growing within the University of Fort Hart Campus at Alice and was authenticated by Tony Dolds at the Albany herbarium in Rhodes University, Grahamstown, South Africa.

\section{Preparation of extracts}

The collected leaves were cleaned of extraneous materials, dried in an oven at a temperature of $40^{\circ} \mathrm{C}$ and later pulverized. About $300 \mathrm{~g}$ of the pulverized samples were extracted with separate solvents (water, ethanol and acetone) on a shaker for $48 \mathrm{~h}$. They were later filtered with a funnel and Whatman filter paper. While the ethanol and acetone extracts of the samples were concentrated at $78^{\circ} \mathrm{C}$ and $56^{\circ} \mathrm{C}$, respectively using a rotary evaporator, the water extracts of both samples were frozen at $-40^{\circ} \mathrm{C}$ with an acetone chiller, then freeze-dried. The extracts were stored away in a refrigerator at $4^{\circ} \mathrm{C}$.

\section{Estimation of total phenol content}

The total phenol was estimated spectrophotometrically by using the Folin-Ciocalteu assay method. ${ }^{16}$ About $0.5 \mathrm{ml}$ of the extract was mixed with $2.5 \mathrm{ml}$ of $10 \%$ Folin-Ciocalteu reagent in tubes, vortexed for about $30 \mathrm{~s}$ and allowed to stand for $10 \mathrm{~min}$ at $25^{\circ} \mathrm{C} .2 \mathrm{ml}$ of $7.5 \%$ anhydrous sodium carbonate was added and vortexed again for another $30 \mathrm{~s}$. The tubes were incubated in a water bath at $40^{\circ} \mathrm{C}$ for $30 \mathrm{~min}$ for colour development and absorbance read at $765 \mathrm{~nm}$ using a spectrophotometer. Gallic acid standards were prepared in the same manner as the extracts as described earlier. The total phenolic content was then expressed as $\mathrm{mg} / \mathrm{g}$ gallic acid (GAE/gm) equivalent.

\section{Estimation of total flavonoid content}

The total flavonoid content was estimated spectrophotometrically by using the aluminum chloride colorimetric assay with some modifications. ${ }^{16}$ The reaction mixture was made up of $0.5 \mathrm{ml}$ of the plant extract, $2 \mathrm{ml}$ of distilled water in a tube and $0.15 \mathrm{ml}$ of $5 \%$ sodium nitrite. The mixture was allowed to stand for $5 \mathrm{~min}$ at room temperature after which $0.15 \mathrm{ml}$ of $10 \%$ aluminum chloride was added to the solution and allowed to incubate for another $5 \mathrm{~min}$. After incubation, $1 \mathrm{ml}$ of $4 \%$ sodium hydroxide was added and the solution made up to $5 \mathrm{ml}$ with distilled water. The solution was then vortexed and incubated for $15 \mathrm{~min}$ to observe a colour change. The absorbance was measured at $420 \mathrm{~nm}$. The total flavonoid content was calculated as $\mathrm{mg} / \mathrm{g}$ quercetin equivalent.

\section{Estimation of total flavonol content}

The total flavonol content was estimated using the method described by Wintola and Afolayan with some modifications. ${ }^{17} 2 \mathrm{ml}$ of the plant extract was added to $2 \mathrm{ml}$ of $10 \%$ aluminum chloride prepared in ethanol. To this $3 \mathrm{ml}$ of $5 \%$, sodium acetate was added and then incubated at $20^{\circ} \mathrm{C}$ for $2^{1} / \mathrm{h}$. The absorbance was measured at $440 \mathrm{~nm}$ with a spectrophotometer. Total flavonol content was expressed as $\mathrm{mg} / \mathrm{g}$ of quercetin equivalent.

\section{Estimation of proanthocyanidin content}

The total proanthocyanidin were estimated using the method described by Caceres- Mella et al. with some modifications ${ }^{18}$ by mixing $0.5 \mathrm{ml}$ of the prepared plant extract with $3 \mathrm{ml}$ of $4 \%$ vanillin-methanol. $1.5 \mathrm{ml}$ of hydrochloric acid was added to the solution and vortexed. The mixture was left to stand for $15 \mathrm{~min}$ at room temperature. The absorbance was then read at $500 \mathrm{~nm}$ using a spectrophotometer. Total proanthocyanidins content was calculated as $\mathrm{mg} / \mathrm{g}$ of catechin equivalents.

\section{Estimation of tannin content}

The total tannin content was estimated using the Folin - Ciocalteu method. ${ }^{16 .} 7.5 \mathrm{ml}$ of distilled water was added to a tube containing $0.1 \mathrm{ml}$ of the plant extract. $0.5 \mathrm{ml}$ of Folin-Ciocalteuphenol reagent and $1 \mathrm{ml}$ of $35 \% \mathrm{Na}_{2} \mathrm{CO}_{3}$ solution was then added. The whole solution was made up to $10 \mathrm{ml}$ with distilled water. The mixture was vortexed and kept at room temperature for $30 \mathrm{~min}$. The absorbance was read at $725 \mathrm{~nm}$ using a spectrophotometer. The total tannin content was expressed as $\mathrm{mg} / \mathrm{g}$ GAE equivalent.

\section{Estimation of alkaloid content}

The total alkaloid content was estimated using the method described by Unuofin et al. ${ }^{19} 5 \mathrm{~g}$ of the pulverized plant was immersed in $200 \mathrm{~mL}$ of $10 \%$ acetic acid in ethanol. The mixture was allowed to stand for $4 \mathrm{hr}$ at room temperature. It was subsequently filtered and the filtrate was 
concentrated using a water bath at $55^{\circ} \mathrm{C}$ to a quarter of its original volume. Concentrated ammonium hydroxide was added in single drops until completion of the precipitation process. The solution was then washed with dilute ammonium hydroxide and filtered again. The residue obtained was first dried and then weighed. The alkaloid content was calculated using the equation:

$$
\% \text { Alkaloid }=\frac{\text { Weight of precipitate }}{\text { Weight of original sample }} \times 100
$$

\section{Estimation of saponin}

The saponin content was determined according to the method described by Omoruyi et al..$^{20}$ with some modifications. $5 \mathrm{~g}$ of the pulverized plant was added to $20 \mathrm{ml}$ of $20 \%$ ethanol and extracted on a shaker for $30 \mathrm{~min}$. The plant sample was heated over a water bath at $55^{\circ} \mathrm{C}$ for four $\mathrm{h}$. The mixture was filtered and the residue was re-extracted again with $20 \mathrm{ml}$ of $20 \%$ aqueous ethanol. The filtrate was then reduced to $40 \mathrm{ml}$ over a water bath at $90^{\circ} \mathrm{C}$. The concentrate was transferred into a $250 \mathrm{ml}$ separatory funnel and extracted twice with $20 \mathrm{ml}$ diethyl ether. The ether layer was discarded while purification process was repeated. Sixty milliliters $(60 \mathrm{ml})$ of n-butanol was added and the extract was washed twice with $10 \mathrm{ml}$ of $5 \%$ aqueous sodium chloride. The remaining solution was heated over a water bath and evaporated to dryness to a constant at $40^{\circ} \mathrm{C}$. The saponin content was calculated using the following equation:

$$
\% \text { Saponins contents }=\frac{\text { Weight of residue }}{\text { Weight of sample }} \times 100
$$

\section{Estimation of phytate}

The total phytate content was estimated using the method described by Unuofin et al. ${ }^{19} 2 \mathrm{~g}$ of the pulverized plant was soaked into a conical flask with $50 \mathrm{ml}$ of $2 \%$ hydrochloric acid for $3 \mathrm{~h}$ and afterward filtered. $25 \mathrm{ml}$ of the filtrate was taken and $5 \mathrm{ml}$ of $0.3 \%$ ammonium thiocyanate solution was added. $53.5 \mathrm{ml}$ of distilled water was also added to achieve the desired acidity. Then $0.05 \mathrm{M}$ of iron III chloride was titrated into it until a reddish brown colour persists for $5 \mathrm{~min}$. Phytate content was calculated as:

$$
\text { Phytate }(\%)=\text { titre value } \times 0.00195 \times 1.19 \times 100 \text {. }
$$

\section{DPPH radical scavenging assay}

DPPH radical scavenging activity of the plant extracts was determined according to the method described by Wintola and Afolayan ${ }^{17}$ with some modifications. A preparation of $1 \mathrm{ml}$ of $0.135 \mathrm{mM} \mathrm{DPPH}$ in methanol was mixed with $1 \mathrm{ml}$ of various concentrations $(0.2-1.0 \mathrm{mg} / \mathrm{ml})$ of the plant extracts, vitamin $\mathrm{C}$ and gallic acid. The mixture was left in the dark at room temperature for $30 \mathrm{~min}$ after being vortexed. The absorbance of the mixture was then measured spectrophotometrically at $517 \mathrm{~nm}$. Both vitamin $\mathrm{C}$ and gallic acid were used as standards. The DPPH radical scavenging activity was calculated from the equation:

DPPH radical scavenging activity $=\frac{\{(\text { Abs control }- \text { Abs sample })\}}{(\text { Abs control })} \times 100$

where Abs control was the absorbance of DPPH radical + methanol; Abs sample was the absorbance of DPPH radical + sample extract or standards (Vitamin $\mathrm{C}$ and gallic acid).

\section{Nitric oxide scavenging activity}

Nitric oxide scavenging activity was determined according to the method described by Boora et al. ${ }^{21}$ with some modifications. $2 \mathrm{ml}$ of $10 \mathrm{mM}$ Sodium nitroprusside was prepared in $0.5 \mathrm{ml}$ phosphate buffer saline (pH 7.4) and mixed with $0.5 \mathrm{ml}$ of either plant extracts, vitamin $\mathrm{C}$ or gallic acid, at various concentrations $(0.2-1.0 \mathrm{mg} / \mathrm{ml})$. The mixture was incubated at $25^{\circ} \mathrm{C}$ for $150 \mathrm{~min}$. After incubation, $0.5 \mathrm{ml}$ of Griess reagent $(1.0 \mathrm{ml}$ of $0.33 \%$ sulfanilic acid reagent prepared in $20 \%$ glacial acetic acid at room temperature for $5 \mathrm{~min}$ with $1 \mathrm{ml}$ of naphthylethylenediamine dichloride) was added to an equal volume of the incubated solution. The mixture was incubated for another $30 \mathrm{~min}$ at room temperature and the absorbance was then measured at $540 \mathrm{~nm}$. The amount of nitric oxide radical inhibited by the extracts was calculated using the following equation:

Nitric oxide $(\mathrm{NO})$ radical scavenging activity $=\frac{\{(\text { Abs control }- \text { Abs sample })\}}{(\text { Abs control })} \times 100$

where Abs control was the absorbance of $\mathrm{NO}$ radical + methanol; Abs sample was the absorbance of NO radical + sample extract or standards (Vitamin $\mathrm{C}$ and gallic acid).

\section{Hydrogen peroxide radical scavenging assay}

Hydrogen peroxide scavenging activity was determined using the method described by Oyedemi et al..$^{22} 4 \mathrm{ml}$ of plant extract, vitamin C or gallic acid was prepared in distilled water at different concentrations $(0.2-1.0 \mathrm{mg} / \mathrm{ml})$ and mixed with $0.6 \mathrm{ml}$ of $4 \mathrm{mM}$ Hydrogen peroxide $\left(\mathrm{H}_{2} \mathrm{O}_{2}\right)$ solution prepared in phosphate buffer $(0.1 \mathrm{M}, \mathrm{pH}$ 7.4). The solution was incubated for $10 \mathrm{~min}$ at room temperature. The absorbance of the solution was then measured at $230 \mathrm{~nm}$. The amount of hydrogen peroxide radical inhibited by the extract was calculated using the following equation:

$$
\mathrm{H}_{2} \mathrm{O}_{2} \text { radical scavenging activity }=\frac{\{(\text { Abs control }- \text { Abs sample })\}}{(\text { Abs control })} \times 100
$$

where Abs control was the absorbance of $\mathrm{H}_{2} \mathrm{O}_{2}$ radical + methanol; Abs sample was the absorbance of the $\mathrm{H}_{2} \mathrm{O}_{2}$ radical + sample extract or standard (Vitamin C and gallic acid).

\section{Phosphomolybdenum antioxidant assay}

The total antioxidant capacity was determined by the method described by Ahmed et al. ${ }^{23}$ with some modifications. $0.5 \mathrm{ml}$ of plant extracts, vitamin $\mathrm{C}$ and gallic acid prepared in varying concentrations (0.1-0.5 $\mathrm{mg} / \mathrm{ml}$ ) were mixed with three $\mathrm{ml}$ of distilled water and $1 \mathrm{mls}$ of phosphomolybdate reagent in test tubes. The solutions were then incubated at $95^{\circ} \mathrm{C}$ for $90 \mathrm{~min}$. After incubation, the tubes were normalized to room temperature for about $30 \mathrm{~min}$. The absorbance of the solution was then measured at $695 \mathrm{~nm}$. The amount of phosphomolybdenate radical inhibited by the extract was calculated using the following equation:

Phosp hom olybdate antioxidant activity $=\frac{\{(\text { Abs control }- \text { Abs sample })\}}{(\text { Abs control })} \times 100$

where Abs control was the absorbance of phosphomolybdate reagent + methanol; Abs sample was the absorbance of phosphomolybdate reagent + sample extract or standard (Vitamin C and gallic acid).

\section{Vitamin A estimation}

Vitamin A estimation was done by the method described by Onyesife et al. ${ }^{24} 20 \mathrm{ml}$ of petroleum ether was added to $1 \mathrm{~g}$ of pulverized plant and 
put on a shaker for about $30 \mathrm{mins}$. The petroleum ether was decanted and evaporated to dryness. $0.2 \mathrm{ml}$ of chloroform-acetic anhydride $(1: 1 \mathrm{v} / \mathrm{v})$ was added to the residue. Later on $2 \mathrm{ml}$ of trichloroacetic acid- chloroform $(1: 1 \mathrm{v} / \mathrm{v})$ was added. The absorbance of the solution was then measured at $620 \mathrm{~nm}$. The vitamin A standard was also prepared in the same way at varying concentrations and a standard curve plotted.

\section{Vitamin C estimation}

Vitamin $\mathrm{C}$ estimation was done by the method described by Igwe and Okwu. ${ }^{25} \mathrm{~A} 1 \mathrm{~g}$ of the pulverised plant was put in $20 \mathrm{ml}$ of $0.4 \%$ oxalic acid. It was then filtered using a Whatman filter paper and $1 \mathrm{ml}$ of the filtrate was mixed with $9 \mathrm{ml}$ of indophenol reagent. The absorbance of the solution was measured at $520 \mathrm{~nm}$. The vitamin $\mathrm{C}$ standard was also prepared in the same way at varying concentrations and a standard curve plotted.

\section{Vitamin E estimation}

Vitamin E estimation was done by the method described by Onyesife et al. ${ }^{24}$ $20 \mathrm{ml}$ of ethanol was added to $0.5 \mathrm{~g}$ of the pulverized sample and then left on a shaker for $20 \mathrm{mins}$. It was then filtered. $1 \mathrm{ml}$ of the filtrate was then mixed with $1 \mathrm{ml}$ of $0.2 \%$ of ferric acid in ethanol and $1 \mathrm{ml}$ of $0.5 \%$ - $\alpha$ dipyridine. The solution was made up to $5 \mathrm{mls}$ with distilled water. The absorbance of the solution was read at $520 \mathrm{~nm}$. The vitamin E standard was also prepared in the same way at varying concentrations and a standard curve plotted.

\section{Statistical analysis}

Data obtained were presented as means \pm SD. All experiments were done in triplicates. The One-way analysis of variance (ANOVA) and the Tukey test were used to determine the differences among the means of the various samples. $\mathrm{P}$ values $<0.05$ were regarded to be significant.

\section{RESULTS}

\section{Phytochemical composition}

The Pelargonium spp are noted for their medicinal benefits in herbal medicine, as a result of its rich composition of phytochemicals. In this study the amount of the various phytochemicals investigated differ among the extracts (Figure 1). The total phenolic content in each of the leaf extract showed varying yields with ethanolic extract showing the highest yield at $385.25 \mathrm{mg}$ of GAE per gram of dried extract, followed by the acetone extract at $299 \mathrm{mg}$ and water at $170.5 \mathrm{mg}$ of GAE per gram of dried extract. The ethanol extract was significantly higher $(P<0.05)$ than the acetone and aqueous extract. The total flavonoid content were $369.65 \mathrm{mg}$ of quercetin equivalent per gram of dried extract for the ethanol extract, the acetone extract $202.3 \mathrm{mg}$ quercetin equivalent per gram of dried extract and aqueous extract $127.2 \mathrm{mg}$ quercetin equivalent per gram of dried extract. The flavonol content of the leaf extracts in this study showed acetone leaf extract $(35.67 \mathrm{mg}$ of quercetin equivalent per gram of dried extract) was slightly higher than the ethanol leaf extract (34.52mg of quercetin equivalent per gram of dried extract). The water extract was the lowest at $16.42 \mathrm{mg}$ of quercetin equivalent per gram of dried extract. The acetone and ethanol extract had significantly higher levels than the aqueous extract $(P<0.05)$. The proanthocyanidin level was highest in the acetone leaf extract $(10.4 \mathrm{mg}$ of catechin equivalent per gram of dried extract). The ethanol and aqueous extracts yielded 8.8 and $5.33 \mathrm{mg}$ of catechin equivalent per gram of dried extract respectively. High levels of tannins were observed in the acetone leaf extract of $P$. inquinans (123.8mg/g GAE per gram of dried extract) compared to the ethanol (73.3mg/g GAE per gram of dried extract) and aqueous leaf extracts $(41.3 \mathrm{mg} / \mathrm{g}$ GAE per gram of dried extract). The acetone extract showed significantly higher levels than the ethanol and the aqueous extracts $(P<0.05)$.

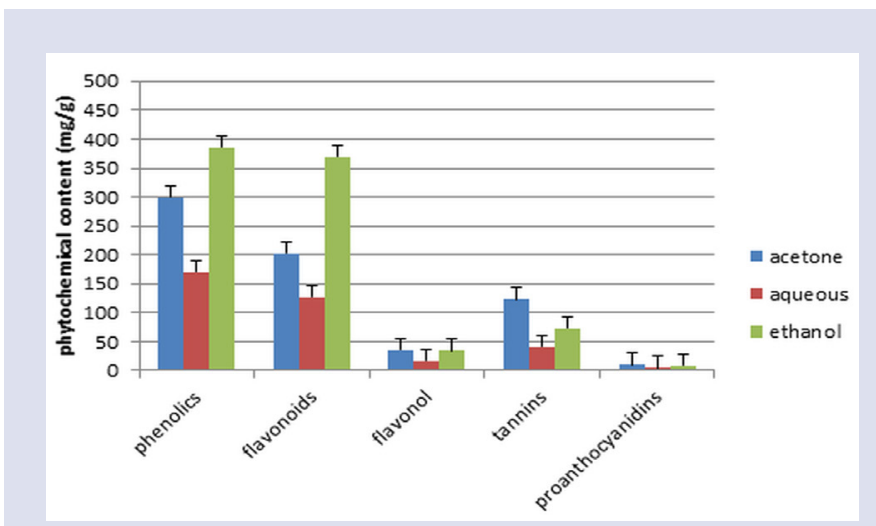

Figure 1: Phytochemical constituents identified in the various extracts of Pelargonium inquinans. Values are expressed as mean \pm standard deviation (SD) of three separate determinations $(n=3)$.

Table 1: Anti-nutrient composition of Pelargonium inquinans leaves.

\begin{tabular}{cc}
\hline Anti-nutrient & Content (\%) \\
\hline Saponin & $36.2 \pm 4.38$ \\
Alkaloid & $0.52 \pm 0.10$ \\
Phytate & $0.65 \pm 0.07$ \\
\hline
\end{tabular}

Table 2: Vitamin contents of Pelargonium inquinans leaves (dried weight).

\begin{tabular}{cc}
\hline Vitamin & Mean \pm SD $(\mathrm{mg} / 100 \mathrm{~g})$ \\
\hline Vitamin A & $1900 \pm 16.4$ \\
Vitamin E & $280.9 \pm 26.2$ \\
Vitamin C & $2.0 \pm 0.02$ \\
\hline
\end{tabular}

The anti-nutrient composition of Pelargonium inquinans leaves showed it contains saponin, alkaloid and phytate in varying percentages (Table 1). These results show that the total phenolic content in this study was higher than the other phytochemicals. Some anti-nutrient are also present in the leaves of Pelargonium inquinans.

\section{Vitamins analysis of Pelargonium inquinans}

This study observed vitamins A, E and C in the dried leaves of Pelargonium inquinans (Table 2). The highest vitamin content was vitamin $\mathrm{A}$ at $1.9 \mathrm{~g} / 100 \mathrm{~g}$ of dried extract. The vitamin E content was $280.9 \mathrm{mg} / 100 \mathrm{~g}$ of dried extract while the vitamin C content was $2.0 \mathrm{mg} / 100 \mathrm{~g}$.

\section{Nitric oxide scavenging activity}

In this study the acetone, aqueous and ethanol extracts of Pelargonium inquinans leaves exhibited a high capacity to scavenge nitrous oxide radicals in a dose-dependent decreasing manner, i.e. the concentration was the inverse of scavenging activity. The aqueous extracts of the plant showed the highest activity at $0.1 \mathrm{mg} / \mathrm{ml}(61.4 \% \pm 0.03)$, higher than the ethanol extract at $60 \% \pm 0.01$ and aqueous extract at $58.7 \% \pm 0.01$ (Figure 2). The acetone extract also had greater activity than gallic acid $(44.5 \% \pm 0.05)$ and Vitamin $C(52 \% \pm 0.03)$. The values were statistically significant $(p<0.05)$. The $\mathrm{IC}_{50}$ values were $0.744,0.741,0.805,1.18$ and $1.18 \mathrm{mg} / \mathrm{ml}$ for acetone, aqueous, ethanol, Vitamin $\mathrm{C}$ and gallic acid respectively. 


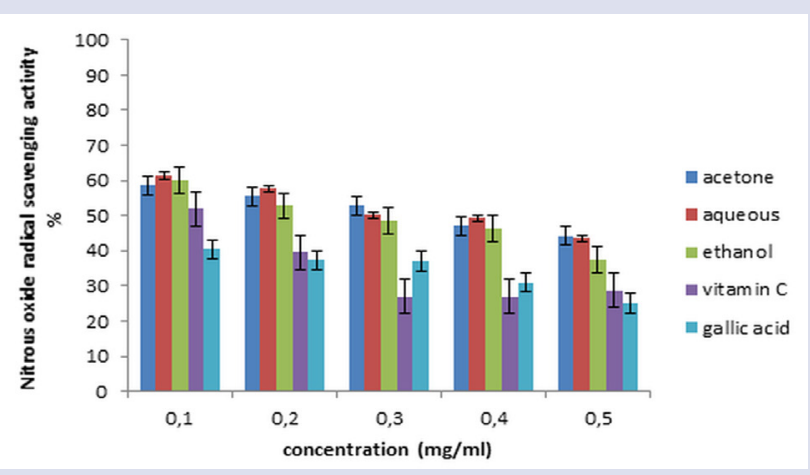

Figure 2: Nitric oxide radical scavenging activity of the extracts of Pelargonium inquinans leaves.

The values represent mean \pm S.D $(n=3) . P<0.05$.

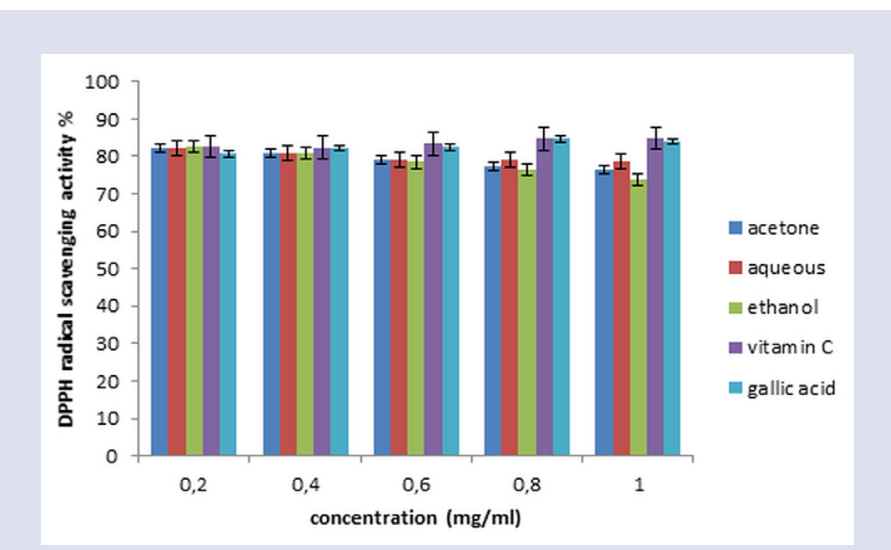

Figure 3: DPPH radical scavenging activity of the extracts of Pelargonium inquinans leaves.

The values represent mean \pm S.D $(n=3) . P>0.05$.

\section{DPPH scavenging activity}

The three solvent extracts of Pelargonium inquinans evaluated scavenged DPPH efficiently. Their scavenging activity at optimal concentration $(0.2 \mathrm{mg} / \mathrm{ml})$ was similar and not statistically different in a dose-dependent decreasing manner, i.e., the concentration was the inverse of scavenging activity. The ethanol extract exhibited the highest scavenging activity at $82.7 \% \pm 0.01$ followed by acetone and aqueous extracts at $82.29 \% \pm 0.01$ and $82.25 \% \pm 0.003 \%$ respectively. All the extracts had lower activity than the standards- vitamin C $(84.9 \% \pm 0.01)$ and gallic acid $(84.65 \% \pm 0.04)$ (Figure 3). The $\mathrm{IC}_{50}$ values were $0.468,0.461,0.476,0.436,0.439 \mathrm{mg} / \mathrm{ml}$ for acetone, aqueous, ethanol, vitamin $\mathrm{C}$ and gallic acid respectively The DPPH scavenging activity of the acetone extract of Pelargonium inquinans recorded in this study was higher than that reported for the acetone extract of Geranium macrorrhizum, though the latter's methanolic extract was higher than Pelargonium inquinans'.

\section{Phosphomolybdenum (total) antioxidant activity}

The aqueous extract of Pelargonium inquinans exhibited a greater antioxidant capacity than the ethanol and acetone extracts. Their antioxidant capacity was in the order aqueous $>$ acetone $>$ ethanol, although less than vitamin C and gallic acid. The IC50 values were $0.293,0.306,0.344$,

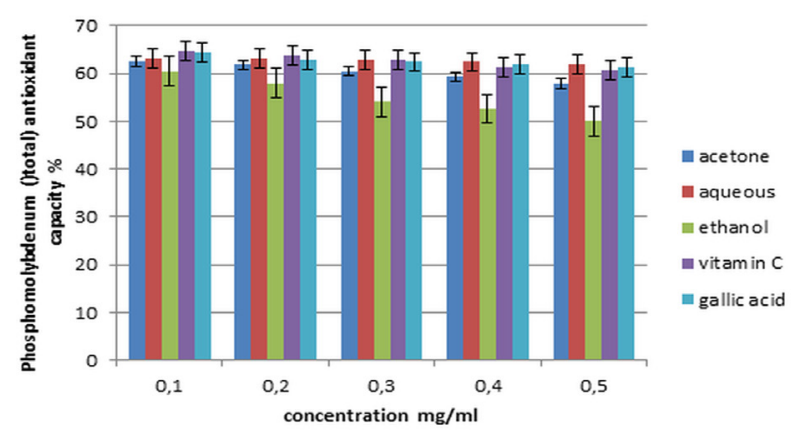

Figure 4: Phosphomolybdenum (total) antioxidant activity of the extracts of Pelargonium inquinans leaves. The values represent mean $\pm S . D(n=3)$.

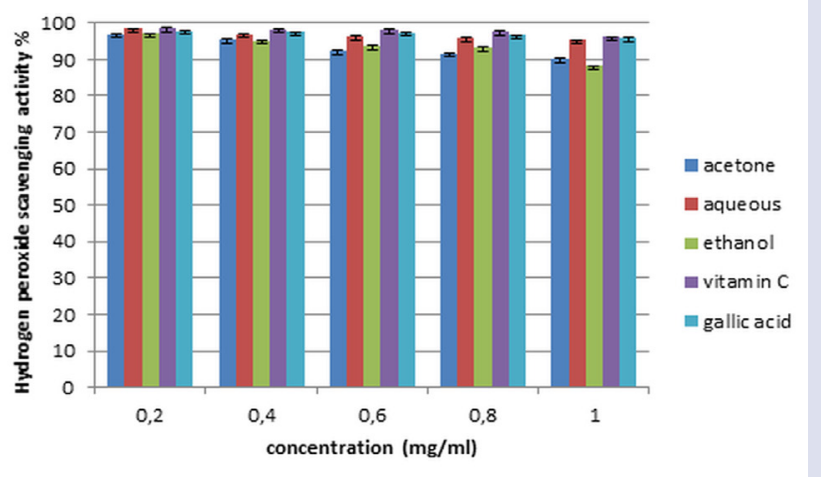

Figure 5: Hydrogen peroxide scavenging activity of the extracts of Pelargonium inquinans leaves extracts. The values represent mean \pm S.D $(n=3)$.

$0.296,0.298 \mathrm{mg} / \mathrm{ml}$ for aqueous, acetone, ethanol, Vitamin C and gallic acid respectively (Figure 4 ). This increased total antioxidant capacity still explains the solvent polarity of the fractions used. Pelargonium spp. are known to have the good antioxidant capacity. However a search of the literature did not reveal any phosphomolybdenum antioxidant capacity work done before and neither did it reveal any too for Pelargonium inquinans.

\section{Hydrogen peroxide scavenging activity}

The results of the hydrogen scavenging scavenging activity of the extracts are as shown in Figure 5. The aqueous extracts of the leaves used had the highest scavenging activity of all the extracts used. The scavenging activity of the extracts were aqueous $98.39 \% \pm 0.009$; acetone $97.11 \%$ \pm 0.008 and ethanol at $96.99 \% \pm 0.04$. The differences were however negligible. There were no significant differences in the activity $(P>0.05)$. The $\mathrm{IC}_{50}$ values were $0.381,0.397,0.397,0.376$ and $0.378 \mathrm{mg} / \mathrm{ml}$ for aqueous, ethanol, acetone, vitamin $\mathrm{C}$ and gallic acid respectively. The aqueous extract was also slightly lower than vitamin $\mathrm{C}$ and gallic acid. A search of the literature did not reveal any information about hydrogen peroxide scavenging ability of Pelargonium inquinans. However, coumarins, compounds consisting of fused benzene and alpha pyrone rings are found abundantly in Pelargonium spp. The hydrogen peroxide 
Izuegbuna, et al:: Estimation of Phytochemical and Vitamins Composition, Antioxidant Activity of Pelargonium inquinans Leaves

scavenging activity of some coumarin derivatives showed that some of them have high hydrogen peroxide scavenging activity, which may explain the high activity observed in all the extracts of Pelargonium inquinans.

\section{DISCUSSION}

\section{Phytochemical composition}

Epidemiological studies have shown that food rich in fruits and vegetables can lower the risk of some chronic diseases. ${ }^{26}$ This effect have been partially linked to the intake of polyphenols and potential mechanism include antioxidation and anti-inflammation. Some studies have reported that polyphenols are efficient antioxidants. ${ }^{27}$ Phenolic compounds have been reported to have many biological activities including antioxidative and anti-neoplastic activities. ${ }^{28}$ The presence of high phenol content may indicate that $P$. inquinans have high antioxidant activity.

Flavonoids are one of the most studied groups of phytochemicals and account for more than half of the natural polyphenols. ${ }^{29}$ They are known to exhibit several biological activities including anti-inflammatory, antioxidant and immunomodulatory properties all which play a role in chronic diseases. Pelargonium spp. leaves are known to be rich in flavonoids and this study further confirmed. Flavanols, also known as flavan-3-ols are a subclass of flavonoids with very complex structures. Flavonols are known to demonstrate good antioxidant and anti-inflammatory activities and are readily distributed in the leaves of Pelargonium spp. Dietary flavonol intake has been shown to be associated with low risk of breast cancer. ${ }^{30}$ Proanthocyanidins are a group of phytochemicals that are readily found in many medicinal plants and are known for their powerful antioxidant activities. ${ }^{31}$ Proanthocyanidins have been reported to have higher antioxidant activity than ascorbic acid and tocopherol. ${ }^{32}$ They are also known to have anti-adhesive activities. ${ }^{33}$ Proanthocyanidin oligomers have been characterized in root extracts of $P$. sidoides, ${ }^{34}$ but they have only moderate pharmacological effects. Pelargonium spp. have been observed to be a rich source of tannins. Although tannins have been reported to be anti-nutritive, they have been discovered to possess biological and pharmacological actions such as antimicrobial, antineoplastic, anti-plasmin inhibitory activity as well as superoxide anion scavenging activity. ${ }^{35}$ Geraniin, a dehydroellagitannin found in Pelargonium spp., especially Geranium thunbergii, has been shown to play an inhibitory role in human melanoma cells by mediating apoptosis through the cleavage of focal adhesion kinase and up-regulation of Fas ligand expression. ${ }^{36}$ The results of this study were similar to what was reported by Petlevski et al. ${ }^{37}$ for the total tannin content using water and ethanolic leaf extracts of $P$. radula, though the result of their aqueous extract was significantly lower than the one obtained in our study.

Pelargonium inquinans leaves is also composed of anti-nutritive factors like alkaloids, saponin and phytate. The Pelargonium spp. have been reported to have some alkaloids. ${ }^{38}$ The indole alkaloids elaeocarpidine and its $20-\mathrm{H}$ isomer epielaeocarpidine were characterized in the leaves of the Pelargonium appleblossom. ${ }^{39}$ Also recently, Igwenyi and Elekwa ${ }^{40}$ were able to quantify the total alkaloid content of the fresh leaves of Geranium robertianum from Nigeria. From a search of the literature, this study appears to be the first to quantify the alkaloid content of Pelargonium. inquinans. The pharmacological importance of alkaloids cannotbeunderstated especially as anticancer agents in the management of many malignancies. ${ }^{41}$ Saponins are known to have medicinal values which include anti-inflammatory, cholesterol-lowering activity as well as antineoplastic activity. The antineoplastic activity is reported to be achieved via anti-angiogenesis and anti-metastasis. ${ }^{42}$ Saponin was present in all the solvent extracts of $P$. graveolens leaves, in a qualitative screening done by Pradeepa et al. ${ }^{43}$ Saponin was also observed in P.luridum. ${ }^{44}$ To the best of our knowledge, this is the first study to report the saponin content in
Pelargonium. inquinans leaves. Phytate also known to be anti-nutritive, but has been discovered to have some health benefits. Some of their pharmacological activity includes lowering of blood sugar and lipids, antioxidants and prevention of nephrolithiasis. ${ }^{45}$

\section{Vitamins}

The study showed that Vitamins A, E and C were present in the leaves of Pelargonium inquinans. Vitamins are well-known nutrient that contributes to health and well-being. Although needed in small amounts they play a vital role in normal body physiology and their deficiencies have been linked to some diseases. ${ }^{46}$ Vitamin $\mathrm{C}$ and $\mathrm{E}$ are well-known antioxidants that play major roles in cells that display oxidative stress including cancer cells. ${ }^{6,7}$ Vitamin A derivatives such as all-trans- retinoic acid are used in the management of acute promyelocytic leukaemia. ${ }^{47}$ Some of these vitamins and their derivatives have been mooted as chemopreventive agents. ${ }^{48}$ The discovery of more sources of these vitamins and their derivatives like Pelargonium spp. can be a way to manage chronic diseases.

\section{Nitric oxide scavenging activity}

Nitric oxide is a well-known free radical with pleiotropic effects across some physiological processes in the body. ${ }^{49}$ It is known to play a role in vasodilatation, smooth muscle relaxation, inhibition of platelet aggregation, immunity. ${ }^{50}$ It is constitutively produced by the body in nanomolar concentration to maintain normal cellular function. However, nitric oxide produced in greater concentration can exacerbate inflammatory processes causing tissue damage. The nitric oxide scavenging activity of Pelargonium inquinans was higher than the standards confirming several reports that showed a close relationship between total phenolic content and high antioxidant activity. ${ }^{51}$

\section{DPPH radical scavenging activity}

Alpha, alpha-diphenyl- $\beta$-picrylhydrazyl (DPPH) is a stable free radical that reacts slowly with most compounds. The method was developed by Blois in 1958 and is based on the ability of the odd nitrogen electron in its molecules to accept a hydrogen atom from a donor antioxidant thereby becoming reduced in the process, i.e., DPPH-H..$^{52}$ Pelargonium inquinans has been shown to exert strong DPPH scavenging with its ethyl acetate fraction showing excellent antioxidative potential. ${ }^{15}$ The compound 1,2,3,4,6-penta-O-galloyl-beta-d-glucose (PGG) is taken as the active antioxidative component. The Pelargonium spp are known to possess antioxidative activity. This study further confirmed it.

\section{Phosphomolybdenum (total) antioxidant activity}

The phosphomolybdenum antioxidant assay is a quantitative method based on the reduction of phosphate-molybdenum (VI) to phosphatemolybdenum (V). This antioxidant assay evaluates the total antioxidant capacity (water-soluble and fat-soluble) of a crude extract. The assay is involved in thermally generating auto-oxidation during extended incubation periods at high temperature. This assay is different from the other reducing assays because it doesn't change form irrespective of the free metal concentration, thus maintaining its green phosphomolybdenum complex form. It is therefore an assay that gives a more direct estimation of reducing capacity of antioxidants. Pelargonium spp. are known to have the good antioxidant capacity. However a search of the literature did not reveal any phosphomolybdenum antioxidant capacity work done before and neither did it reveal any too for Pelargonium inquinans.

\section{Hydrogen peroxide scavenging activity}

Hydrogen peroxide is an important reactive oxygen species that is formed as a result of the enzymatic conversion of superoxide radical by superoxide dismutase. It is then either converted to water by catalase 
or to hydroxyl radical in the Fenton reaction. Hydrogen peroxide is cytotoxic to cells and it is used by the body to fight bacterial and also to enhance the process of inflammation..$^{53}$ The product of hydrogen peroxide catalysis, hydroxyl ion is regarded as the most reactive of all reactive oxygen species capable of causing lipid peroxidation, protein damage and membrane damage..$^{54}$ Due to its role in inflammation and cell damage, control of the cellular level of hydrogen peroxide is important. The scavenging ability of Pelargonium inquinans was high and dosedependent. This could be as a result of high levels of phenolic compounds and flavonoids; compounds with high amounts of polyphenol have good antioxidant activities. ${ }^{55}$ Thus the high antioxidant activity in the different extracts of Pelargonium inquinans could be as a result of the high amount of phenolic compounds and flavonoids.

\section{CONCLUSION}

The antioxidative abilities of extracts from plant sources is of great interest to researchers and industry because of their medicinal properties in the definitive and supportive care of cancer. This study investigated the phytochemical composition, vitamin content and antioxidative properties of Pelargonium inquinans. The study showed that different phytochemicals and anti-nutrients were present in varying amounts. The various antioxidant assays done showed that extracts of Pelargonium inquinans have strong antioxidant activities which makes them potential candidates in the management of cancers.

\section{ACKNOWLEDGEMENT}

Authors would like to extend their appreciation to Professor Afolayan, of the Medicinal Plants and Economic Development, University of Fort Hare for his support.

\section{CONFLICT OF INTEREST}

The authors declare no conflict of interest.

\section{ABBREVIATIONS}

DPPH: Alpha, alpha-diphenyl- $\beta$-picrylhydrazyl; OS: Oxidative stress; ROS: Reactive oxygen species; RNS: Reactive nitrogen species; $\mathbf{H}_{2} \mathbf{O}_{2}$ : Hydrogen peroxide; PGG: 1,2,3,4,6-penta-O-galloyl-beta-d-glucose; NO: Nitric oxide.

\section{REFERENCES}

1. ZhouY, Zheng J, LiY, Xu DP, Li S, Chen YM, et al. Natural Polyphenols for Prevention and Treatment of Cancer. Nutrients. 2016;8(8):515.

2. Valko M, Leibfritz D, Moncol J, Cronin MT, Mazur M, Telser J. Free radicals and antioxidants in normal physiological functions and human disease. Int $J$ Biochemistry and Cell Biology. 2007;39(1):44-84.

3. Finkel T, Holbrook NJ. Oxidants, oxidative stress and the biology of ageing. Nature. 2000;408(6809):239-7.

4. Udensi UK, Tchounwou PB. Dual effect of oxidative stress on leukemia cancer induction and treatment. Journal of Experimental and Clinical Cancer Research: CR. 2014;33(1):106.

5. Rizzo AM, Berselli P, Zava S, Montorfano G, Negroni M, Corsetto P, et al. Endogenous antioxidants and radical scavengers. Advances in Experimental Medicine and Biology. 2010;69(8):52-67.

6. Rizvi S, Raza ST, Ahmed F, Ahmad A, Abbas S, Mahdi F. The Role of Vitamin E in Human Health and Some Diseases. Sultan Qaboos University Medical Journal. 2014;14(2):e157-65.

7. Montecinos V, Guzmán P, Barra V, Villagrán M, Muñoz-Montesino C, et al. Vitamin $C$ is an Essential Antioxidant That Enhances Survival of Oxidatively Stressed Human Vascular Endothelial Cells in the Presence of a Vast Molar Excess of Glutathione. The Journal of Biological Chemistry. 2014;282(21):1550615.

8. Maraldi T, Prata C, Vieceli DF, Caliceti C, Zambonin L, Fiorentini D, et al. NAD(P) $\mathrm{H}$ oxidase isoform Nox2 plays a prosurvival role in human leukaemia cells. Free Radic Res. 2009;43(11):1111-21.

9. Arnold RS, He J, Remo A, Ritsick D, Yin-Goen Q, Lambeth JD, et al. Nox1 expression determines cellular reactive oxygen and modulates c-fos-induced growth factor, interleukin-8 and Cav-1. Am J Pathol. 2007;171(6):2021-32.

10. Wu WS, Wu JR, Hu CT. Signal cross talks for sustained MAPK activation and cell migration: the potential role of reactive oxygen species. Cancer Metastasis Rev. 2008;27(2):303-14.

11. Trachootham D, Alexandre J, Huang P. Targeting cancer cells by ROS-mediated mechanisms: a radical therapeutic approach?. Nat Rev Drug Discov. 2009;8(7):579-91.

12. Sallmyr A, Fan J, Rassool FV. Genomic instability in myeloid malignancies: Increased Reactive oxygen species (ROS), DNA Double strand breaks (DSBs) and error-prone repair. Cancer Lett. 2008;270(1):1-9.

13. Battisti V, Maders LD, Bagatini MD, Santos KF, Spanevello RM, Maldonado PA, et al. Measurement of oxidative stress and antioxidant status in acute lymphoblastic leukemia patients. Clin Biochem. 2008;41(7-8):51-18.

14. http://pza.sanbi.org/pelargonium-inquinans.

15. Piao X, Piao XL, Kim HY, Cho EJ. Antioxidative activity of geranium (Pelargonium inquinans Ait) and its active component, 1,2,3,4,6-Penta-O-galloyl- $\beta$-d-glucose. Phytotherapy Research. 2008;22(4):534-8.

16. Vijay T, Bhambar RS. Estimation of Total Phenol, Tannin, Alkaloid and Flavonoid in Hibiscus Tiliaceus Linn. Wood Extracts. Research and Reviews: Journal of Pharmacognosy and Phytochemistry. 2014;2(4):41-7.

17. Wintola OA, Afolayan AJ. Phytochemical constituents and antioxidant Activities of the whole leaf extract of Aloe ferox Mill. Pharmacognosy Magazine. $2011 ; 7(28): 325-33$

18. Cáceres-Mella A, Peña-Neira Á, Narváez-Bastias J, Jara-Campos C, López-Solís R, Canals JM. Comparison of analytical methods for measuring proanthocyanidins in wines and their relationship with perceived astringency. International Journal of Food Science and Technology. 2013;48(12):2588-94.

19. Unuofin JO, Otunola GA, Afolayan JA. Phytochemical screening and in vitro evaluation of antioxidant and antimicrobial activities of Kedrostis africana (L.) Cogn. Asian Pac J Trop Biomed. 2017;7(10):901-8.

20. Omoruyi BE, Bradley G, Afolayan AJ. Antioxidant and phytochemical properties of Carpobrotus edulis (L.) bolus leaf used for the management of common infection in HIV/AIDS patients in Eastern Cape Province. BMC Complementary and Alternative Medicine. 2012;12(1):215.

21. Boora F, Chirisa E, Mukanganyama S. Evaluation of Nitrite Radical Scavenging Properties of Selected Zimbabwean Plant Extracts and Their Phytoconstituents. Journal of Food Processing. 2014. dx.doi.org/10.1155/2014/918018.

22. Oyedemi SO, Bradley G, Afolayan AJ. In vitro and In vivo antioxidant activities of aqueous extract of Strychonos henningsii Gilg. Afri J Pharm Pharmacol. 2010;4(2):70-8.

23. Ahmed D, Khan MM, Saeed R. Comparative Analysis of Phenolics, Flavonoids and Antioxidant and Antibacterial Potential of Methanolic, Hexanic and Aqueous Extracts from Adiantum caudatum Leaves. Antioxidants. 2015;4(2):394-9.

24. Onyesife CO, Ogugua VN, Anaduaka EG. Investigation of some important phytochemicals, vitamins and mineral constituents of ethanol leaves extract of Piper Nigrum. Annals of Biological Research. 2014;5(6):20-5.

25. Igwe OU, Okwu DE. Investigation of the chemical composition of brachystegia eurycoma harms plant parts used in herbal medicine. Int. Res J Pharm. App Sci. 2013;3(6):51-5.

26. Pandey KB, Rizvi SI. Plant polyphenols as dietary antioxidants in human health and disease. Oxidative Medicine and Cellular Longevity. Phytomedicine. 2009;2(5):270-8.

27. Williams RJ, Spencer JP, Rice-Evans C. Flavonoids: antioxidants or signalling molecules?. Free Radic Biol Med. 2004;36(7):838-49.

28. Afari S, Saeidnia S, Abdollahi M. Role of natural phenolic compounds in cancer chemoprevention via regulation of the cell cycle. Current Pharmaceutical Biotechnology. 2014;15(4):409-21.

29. Neveu V, Perez-Jiménez J, Vos F, et al. Phenol-Explorer: an online comprehensive database on polyphenol contents in foods. Database: The Journal of Biological Databases and Curation. 2010.

30. Adebamowo CA, Cho E, Sampson L, Katan MB, Spiegelman D, Willett WC et al. Dietary flavonols and flavonol-rich foods intake and the risk of breast cancer. Int J Cancer. 2005;114(4):628-33

31. Shi J, Yu J, Pohorly JE, Kakuda Y. Polyphenolics in grape seeds-biochemistry and functionality. J Med Food. 2003;6(4):291-9.

32. Beninger CW, Hosfield GL. Antioxidant activity extracts condensed tannin fractions and pure flavanoids from Phaseolus vulgaris $L$. seed coat colour genotypes. Journal of Agricultural and Food Chemistry. 2003;51(27):7879-83.

33. Janecki A, Conrad A, Engels I, Frank U, Kolodziej H. Evaluation of an aqueousethanolic extract from Pelargonium sidoides (EPs ${ }^{\circledR} 7630$ ) for its activity against group A-streptococci adhesion to human HEp-2 epithelial cells. Journal of Ethnopharmacology. 2011;133(1):147-52

34. Schotz K, Noldner M. Mass spectroscopic characterization of oligomeric proanthocyanidins derived from an extract of Pelargonium sidoides roots (EPs ${ }^{\circledR} 7630$ ) and pharmacological screening in CNS models. Phytomedicine. 2007;14(5):32-9.

35. Okuda T, Ito H. Tannins of Constant Structure in Medicinal and Food PlantsHydrolyzable Tannins and Polyphenols Related to Tannins. Molecules. 
2011;16(3):2191-217.

36. Lee JC, Tsai CY, Kao JY, Kao MC, Tsai SC, Chang CS, et al. Geraniin-mediated apoptosis by cleavage of focal adhesion kinase through up-regulation of Fas ligand expression in human melanoma cells. Molecular Nutrition and Food Research. 2008;52(6):655-63.

37. Petlevski R, Flajs D, Kalodera Z, Koncic MZ. Composition and antioxidant activity of aqueous and ethanolic Pelargonium radula extracts. South African Journal of Botany. 2013;85:17-22.

38. Saraswathi J, Venkatesh K, Baburao N, Hilal MH, Rani AR. Phytopharmacological importance of Pelargonium species. Journal of Medicinal Plants Research. 2011;5(13):2587-98.

39. Lis BM, Buchbauer G, Ribisch K, Enger MT. Comparative antibacterial effects of novel Pelargonium essential oils and solvent extracts. Letters in Applied Microbiology. 1998;27(3):135-41

40. Igwenyi 1O, Elekwa AE. Phytochemical Analysis and Determination of Vitamin Contents of Geranium Robertianum. Journal of Dental and Medical Sciences. 2014;13:44-7.

41. Isah T. Anticancer Alkaloids from Trees: Development into Drugs. Pharmacognosy Reviews. 2016;10(20):90-9.

42. Zeng, KW, Song FJ, Li N, Dong $X$, Jiang $Y$, et al. A bioactive steroidal saponin from Ophitopoginjaponicas, inhibits angiogenesis through interruption of SRC tyrosine kinase-dependent matrix metalloproteinase pathway. Basic and Clinical Pharmacology and Toxicology. 2015;116:115-23

43. Pradeepa M, Kalidas V, Geetha N. Qualitative and quantitative phytochemical analysis and bactericidal activity of Pelargonium graveolens L'Her. Int J App Pharm. 2016;8(3):7-11.

44. Saheed S, Tom AOO. Antimicrobial and antidiarrheal activities of Pelargonium Iuridum (Andrews) sweet root extracts. Pharmacologia. 2016;7:202-10.

45. Schlemmer U, Frølich W, Prieto RM, Grases F. Phytate in foods and significance for humans: food sources, intake, processing, bioavailability, protective role and analysis. Mol Nutr Food Res. 2009;53(2):S330-75.

46. Traber MG, Stevens JF. Vitamins $C$ and E: Beneficial effects from a mechanistic perspective. Free Radical Biology and Medicine. 2011;51(5):1000-13.

47. Sanz MA, Montesinos P, Rayón C, Holowiecka A, Serna JDL, Milone G, et al. (on behalf of the PETHEMA and HOVON Groups). Risk-adapted treatment of acute promyelocytic leukaemia based on all-trans retinoic acid and anthracycline and addition of cytarabine in consolidation therapy for high-risk patients: further improvement in treatment outcome. Blood. 2010;115:5137-46.

48. Freemantle SJ, Spinella MJ, Dmitrovsky E. Retinoids in cancer therapy and chemoprevention: promise meets resistance. Oncogene. 2003;22(47):7305-15.

49. Bescós R, Sureda A, Tur JA, Pons A. The effect of nitric-oxide-related supplements on human performance. Sports Med. 2012;42(2):99-117.

50. Jagetia GC, Baliga MS, Malagi KJ, Kamath MS. The evaluation of the radioprotective effect of Triphala (an ayurvedic rejuvenating drug) in the mice exposed to $\gamma$-radiation. Phytomedicine. 2002;9(2):99-108.

51. Li H, Wang X, Li Y, Li P, Wang H. Polyphenolic compounds and antioxidant properties of selected China wines. Food Chem. 2009;112(2):454-60.

52. Kedare SB, Singh RP. Genesis and development of DPPH method of antioxidant assay. Journal of Food Science and Technology. 2011;48(4):412-22.

53. Halliwell $B$, et al. Hydrogen peroxide in the human body. FEBS Letters. 2000;486(1); 10-3.

54. Sharma P, Jha AB, Dubey RS, Pessarakli M. Reactive Oxygen Species, Oxidative Damage and Antioxidative Defense Mechanism in Plants under Stressful Conditions. Journal of Botany. 2012;32:243-7. dx.doi.org/10.1155/2012/217037.

55. Lin JT, Liu SC, Kuo LC, Yang DJ. Composition of phenolic compounds and antioxidant attributes of Cyclea gracillima Diels extracts. Journal of Food and Drug Analysis. 2018;26(1):193-200

\section{ABOUT AUTHORS}

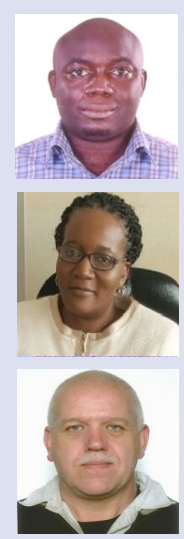

\section{SUMMARY}

- This work investigated the chemical composition of a member of the Geraniceae family, Pelargonium inquinans Ait. It estimated its phytochemical contents as well as the composition of vitamins $A, C$ and $E$. It also investigated the antioxidant activity of the plant extracts. The extracts were found to be rich in phytochemicals especially phenolics, flavonoids and tannins. They also showed good antioxidant activities and thus justified their use in folk medicine for the management of some ailments.

Dr GA Otunola, Postdoctoral fellow, Medicinal Plants and Economic Development (MPED) Research Center, University of Fort Hare.

Prof. Graeme Bradley, Plant Stress Response Group, University of Fort Hare.

Cite this article: Izuegbuna $\mathrm{O}$, Otunola G, Bradley G. Estimation of Phytochemical and Vitamins Composition, Antioxidant Activity of Pelargonium inquinans Leaves. Pharmacog J. 2019;11(2):237-44. 